\title{
Induced sterility in fish and its potential and challenges for aquaculture and germ cell transplantation technology: a review
}

\author{
Amin Golpour $^{1 *}$, Mohammad Abdul Momin Siddique ${ }^{1}$, \\ Diógenes Henrique SiqueIRA-Silva ${ }^{2} \&$ Martin PŠEnIČKA ${ }^{1}$ \\ ${ }^{1}$ University of South Bohemia in České Budějovice, Faculty of Fisheries and Protection of Waters, South Bohemian Research \\ Center of Aquaculture and Biodiversity of Hydrocenoses, Research Institute of Fish Culture and Hydrobiology, Zátiši 728/II, \\ 38925 Vodñany, Czech Republic; e-mail: dehsari@frov.jcu.cz \\ ${ }^{2}$ UNESP University Estadual Paulista, Campus de São José do Rio Preto, Programa de Pós-Graduação em Biologia Animal, \\ São Paulo, Brazil
}

\begin{abstract}
Interest in reproductively sterile fish in aquaculture has prompted research into their production. Several methods are available for inducing sterility and optimizing its application in the global fishery industry. Sterilization can potentially be accomplished through irradiation, surgery, or chemical and hormonal treatment. Alternative approaches include triploidization, hybridization, and generation of new lines via advanced biotechnological techniques. Triploids of many commercially important species have been studied extensively and have been produced on a large scale for many years. Novel approaches, including disruption of gonadotropin releasing hormone signalling and genetic ablation of germ cells, have been developed that are effective in producing infertile fish but have the disadvantage of not being $100 \%$ reliable or are impractical for large-scale aquaculture. We review currently used technologies and recent advances in induction of sterility in fish, especially those intended for use in germ cell transplantation. Knowledge of the implications of these approaches remains incomplete, imposing considerable limitations.
\end{abstract}

Key words: sterility; reproductive containment; germ cell; biotechnological tools.

Abbreviations: dnd, dead end; dsRNA, double-stranded RNA; GFP, green fluorescent protein; GnRH, gonadotropin releasing hormone; GSI, gonadosomatic index; MOs, modified oligonucleotides; PGCs, primordial germ cells; qPCR, quantitative PCR; siRNA, small interfering RNA; Sdf1a, stromal-derived factor-1alpha.

\section{Introduction}

Culture of commercially important fish species largely depends on continuous production by breeding in captivity. A worldwide decline in natural resources calls for strategies to restore endangered species. According to the most recent report on global fisheries, the catch of wild fish has been gradually decreasing for years (OCED/FAO Agricultural outlook 2011-2020, Chapter 8). The aquaculture industry is exploring efficient and reliable procedures for fish rearing that might also apply to species not currently being cultured under artificial conditions. Biotechnological advances have made it profitable to induce differentiation and maturation of functional gametes for production of a number of artificially cultured fish species (Yamaha et al. 2007). One approach to optimizing aquaculture production in an environmentally sustainable way is the rearing of sterile fish through approaches, such as triploidization, hybridization, hyperthermia, irradiation, surgery, and chemical and hormonal treatment (Tashiro 1972; Arai et al. 2001; Bartley et al. 2001; Ito et al. 2008a,b; Wong et al. 2011). Commercial advantages of sterile fish include increased growth rate, improved flesh quality, disease resistance, and increased environmental tolerance (Hallerman \& Kapuscinsky 1995; Bartley et al. 2001; Rahman et al. 2005; Um-E-Kalsoom et al. 2009).

Fish sterilization by surgery was probably the first approach used. Several authors have shown successful inhibition of gonad development in some teleost species through surgery and irradiation by X-rays and $\gamma$ rays (Bonham \& Donaldson 1972; Tashiro 1972; Underwood et al. 1986; Bart \& Dunham 1990; Kucharczyk et al. 2008). These procedures may not result in permanent sterilization, since fish show the ability to regenerate gonad tissue (Kobayashi \& Mogami 1958; Underwood et al. 1986). Recent progress in generating sterile fish through biotechnological techniques has led to their use in culture of commercially important species. Application of chemicals, such as busulfan in conjunction with temperature modifications is a promising approach to interrupting gonad develop-

\footnotetext{
* Corresponding author
} 
ment (Brinster \& Avarbock 1994; Brinster 2002; Lacerda et al. 2006). Triploidization is a further biotechnological approach to producing sterile fish (Banfey 1999). The induction of triploidy through application of hydrostatic pressure, elevated temperature, or chemical shock at a critical point after fertilization generally produces impaired gametogenesis (Hallerman \& Kapuscinski 1993; Benfey 1999; Sui et al. 2002). The success rate of sterility via triploidization varies according to species, sex, method of treatment, and egg quality.

Hybridization is a commonly used method to induce sterility in fish. Apart from other advantages, infertility of hybrid fish provides the potential for utilization as hosts in germ cell transplantation. However, many hybrids of both freshwater and marine species may not be fully infertile (Allen \& Wattendorf 1987; Smith 1988; Verdegem et al. 1997). Few studies have reported using hybridized sterile fish in germ cell transplantation (Yamaha et al. 2003; Wong et al. 2011).

Genetic ablation of germ cells is also effective in producing sterile fish ( $\mathrm{Hu}$ et al. 2009; Hsu et al. 2010; Wong \& Collodi 2013), but has disadvantages and results in sterility of only one generation. It may not achieve complete sterility.

Creation of sterile fish produced via novel tools may facilitate the production of a germline chimera for germ cell transplantation in vitro and its possible use in commercial aquaculture. This review summarizes the current commonly-used approaches for generating sterile fish and evaluates methods of inducing sterility for germ cell transplantation.

\section{Methods of fish sterilization}

\section{Thermo-chemical treatment}

Recently, thermal treatment alone or in combination with busulfan has been tested to suppress gametogenesis. Exposure of the South American atherinids Argentinian silverside Odontesthes bonariensis and Patagonian pejerrey Patagonina hatcheri to water temperature of $29^{\circ} \mathrm{C}$ for $1-5$ weeks post-hatching was shown to result in gonad degeneration, apoptosis of somatic and germ cells, and severe germ cell depletion (Strüssmann et al. 1998; Ito et al. 2008a,b). The application of busulfan in association with elevated temperature has shown success and is a promising approach to eliminating germ cells (Brinster \& Avarbock 1994; Brinster 2002; Lacerda et al. 2006, 2008). The use of busulfan to induce sterilization in fish was first reported by Billard (1982) in rainbow trout Oncorhynchus mykiss, but attempts were unsuccessful, possibly due to the water temperature, since fish were reared at their optimal growing temperature.

Recently, research has been reported on the use of busulfan in combination with high water temperature to deplete host germ cells, creating an ideal environment for transplanted germ cell colonization, proliferation, and development. Depletion of spermatogenesis has been obtained with a single busulfan injection of

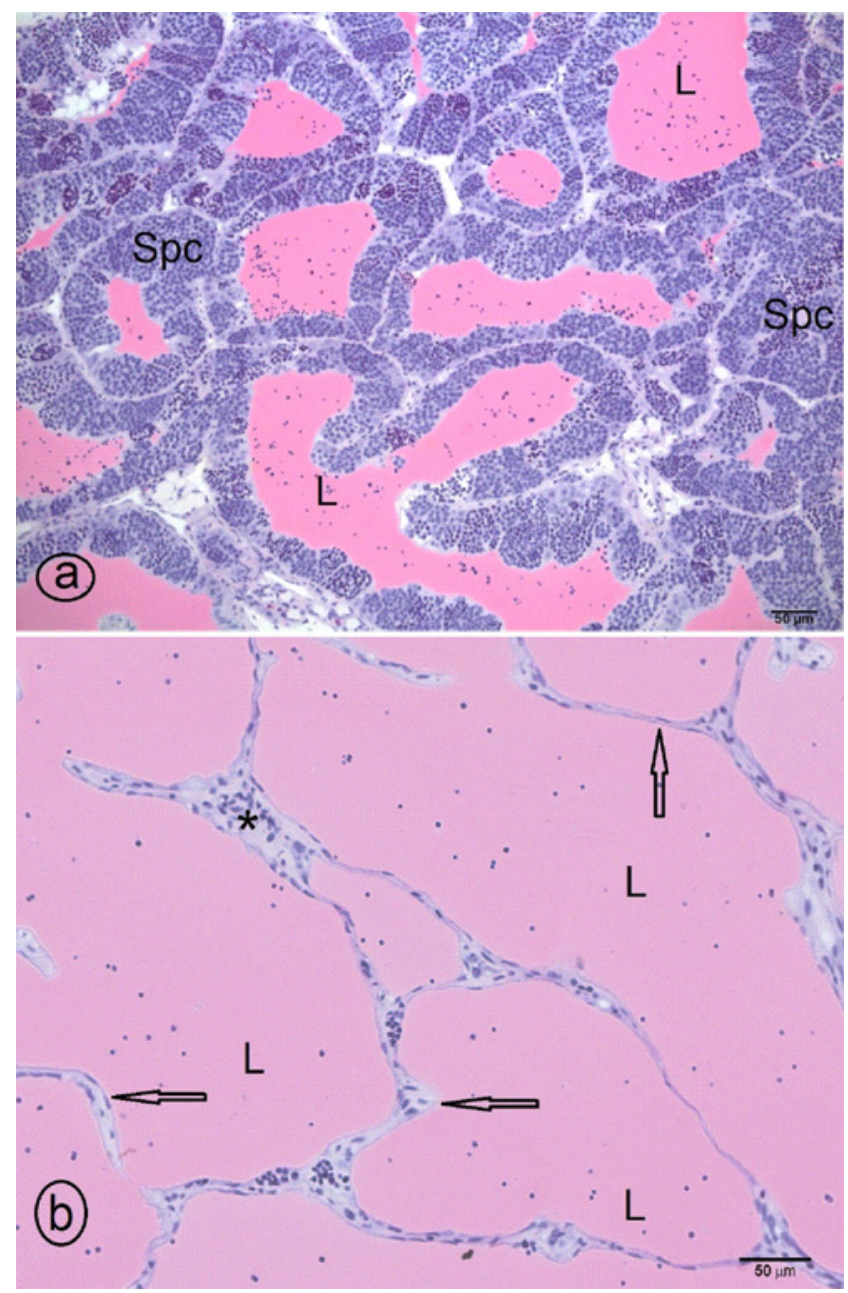

Fig. 1. Testis sections of sexually mature of Astyanax altiparanae. (a) Control fish (kept at $28^{\circ} \mathrm{C}$ ): spermatogenic cysts appear normal with high concentration of spermatocysts (Spc); (b) Fish kept at $35^{\circ} \mathrm{C}$ and treated with busulfan: 42 days post-treatment endogenous spermatogenesis is severely depleted with no spermatocysts and the lumen (L) and interstitium (*) expanded. Arrow represents sertoli cell.

$40 \mathrm{mg} / \mathrm{kg}$ fish body weight at temperatures of $25-26^{\circ} \mathrm{C}$ and $35^{\circ} \mathrm{C}$ in $O$. bonariensis and zebrafish Danio rerio, respectively (Majhi et al. 2009a,b; Nobrega et al. 2010). Lacerda et al. (2010) and de Siqueira-Silva et al. (2015) obtained similar results with two injections of busulfan at $18 \mathrm{mg} / \mathrm{kg}$ and $15 \mathrm{mg} / \mathrm{kg}$ body weight in Nile tilapia Oreochromis niloticus and tetra Astyanax altiparanae, respectively (Fig. 1). Four busulfan injections $(30 \mathrm{mg} / \mathrm{kg}$ and $40 \mathrm{mg} / \mathrm{kg}$ for females and males, respectively) administered at $26^{\circ} \mathrm{C}$ to $O$. hatcheri produced gonad germ cell degeneration and a sterility rate of $80-90 \%$ (Majhi et al. 2014). Recently, Pacchiarini et al. (2014) reported transient sterilization of Senegalese sole Solea senegalensis with a single busulfan injection of $40 \mathrm{mg} / \mathrm{kg}$. Although these strategies are effective, some germ cells remained after treatment (Bucci \& Meistrich 1987; França et al. 1998) resulting in fish that were not completely sterile. It should be noted that busulfan administration may produce sublethal effects on somatic tissues including pyknosis in liver, and in- 
Table 1. Methods of inducing gonadal sterility in important aquaculture and laboratory model fish species.

\begin{tabular}{|c|c|c|c|}
\hline Fish & Method & Result & References \\
\hline Oncorhynchus mykiss & $\begin{array}{l}\text { Irradiation of } \gamma \text {-ray on eyed } \\
\text { egg }\end{array}$ & Sterile & Tashiro (1972) \\
\hline Oncorhynchus mykiss & Heat shock induced triploidy & Undeveloped ovarian tissue & Solar et al. (1984) \\
\hline Oncorhynchus mykiss & $\begin{array}{l}\text { Triploidization by tetraploid } \\
\times \text { diploid cross }\end{array}$ & $\begin{array}{l}\text { Males produced small amount } \\
\text { of aneuploid sperm }\end{array}$ & Chourrout et al. (1986) \\
\hline Oncorhynchus mykiss & $\begin{array}{l}\text { Blocking sGnRH expression } \\
\text { using antisense sGnRH in } \\
\text { transgenic line }\end{array}$ & No sterility & Uzbekova et al. (2000) \\
\hline Oncorhynchus mykiss & Heat shock induced triploidy & $\begin{array}{l}\text { Gonadal sterility in both } \\
\text { sexes }\end{array}$ & Felip et al. $(1999,2001)$ \\
\hline Dicentrarchus labrax & $\begin{array}{l}\text { Hydrostatic shock induced } \\
\text { triploidy }\end{array}$ & Full sterility & Peruzzi et al. (2004) \\
\hline Oncorhynchus kisutch & $\begin{array}{l}\text { Heat and hydrostatic shock } \\
\text { induced triploidy }\end{array}$ & $\begin{array}{l}\text { Gonad sterility in female and } \\
\text { aneuploid sperm in males }\end{array}$ & Withler et al. (1995) \\
\hline Salmo salar & $\begin{array}{l}\text { Heat and hydrostatic shock } \\
\text { induced triploidy }\end{array}$ & $\begin{array}{l}\text { Not fully sterile and unable to } \\
\text { produce viable offspring }\end{array}$ & Benfey \& Sutterlin (1984b) \\
\hline Scophthalmus maximus & Heat shock induced triploidy & $\begin{array}{l}\text { Complete sterility in both } \\
\text { sexes }\end{array}$ & Cal et al. (2006) \\
\hline Oreochromis niloticus & Heat shock induced triploidy & $\begin{array}{l}\text { Gonad development retarded } \\
\text { in both sexes }\end{array}$ & Byamungu et al. (2001) \\
\hline Oreochromis niloticus & $\begin{array}{l}\text { Blocking sGnRH expression } \\
\text { using antisense sGnRH in } \\
\text { transgenic line }\end{array}$ & Gonad sterility in female & Maclean et al. (2003) \\
\hline Oreochromis niloticus & $\begin{array}{l}\text { Thermo-chemical treatment } \\
\text { (busulfan) }\end{array}$ & $\begin{array}{l}\text { Partially gonad sterility in } \\
\text { male }\end{array}$ & Lacerda et al. (2010) \\
\hline Cyprinus carpio & $\begin{array}{l}\text { Thermal shock induced } \\
\text { triploidy }\end{array}$ & $\begin{array}{l}\text { Full gonadal sterility in male } \\
\text { and female }\end{array}$ & Cherfas et al. (1994) \\
\hline Cyprinus carpio & $\begin{array}{l}\text { Blocking sGnRH expression } \\
\text { using antisense sGnRH in } \\
\text { transgenic line }\end{array}$ & Fully sterile gonad & Hu et al. (2007) \\
\hline $\begin{array}{l}\text { Ctenopharyngodon idella } \times H y- \\
\text { pophthalmichthys nobilis }{ }^{a}\end{array}$ & Intra-specific hybridization & $\begin{array}{l}\text { Generally sterile, with a small } \\
\text { proportion diploid and fertile } \\
\text { cells }\end{array}$ & Allen \& Wattendorf (1987) \\
\hline $\begin{array}{l}\text { Salmo trutta } \times \text { Salvelinus } \\
\text { fontinalis }^{a}\end{array}$ & Intra-specific hybridization & Full gonadal sterility & Scheerer \& Thorgaard (1983) \\
\hline $\begin{array}{l}\text { Oreochromis niloticus } \times \text { Oreo- } \\
\text { chromis aureus }\end{array}$ & Intra-specific hybridization & Fertile hybrid & $\begin{array}{l}\text { Wohlfarth (1994); Verdegem } \\
\text { et al. (1997) }\end{array}$ \\
\hline Danio rerio & $\begin{array}{l}\text { Knockdown nanos1 gene using } \\
\text { MOs }\end{array}$ & Complete female sterility & Draper et al. (2007) \\
\hline
\end{tabular}

${ }^{a}$ Crossing between the two organisms.

crease of melanomacrophage centres (Pacchiarini et al. 2014).

\section{Triploidy}

Induction of triploidy has been broadly regarded as an effective method of producing sterile fish for aquaculture and fishery management (Benfey 1999; Piferrer et al. 2009; Fraser et al. 2012). Triploidization of fish can be achieved by the application of hydrostatic pressure (Benfey et al. 1988; Peruzzi \& Chatain 2000; Xu et al. 2008), cold (Felip et al. 1997; Holmefjord \& Refstie 1997; Piferrer et al. 2000; Piferrer et al. 2003) or heat shock (Rougeot et al. 2003), and chemical treatment (Beaumont \& Fairbrother 1991). These applications are applied for a specific period of time at a critical point post-fertilization to disrupt the extrusion of the second polar body from the egg during meiosis. Triploidy can also be achieved by crossing diploid with tetraploid fish (Francescon et al. 2004; Nam \& Kim 2004). The main outcome of triploidization is gonadal sterility, which is of advantage in aquaculture, since it results in superior growth and does not lead to increased incidence of disease or deterioration of flesh organoleptic properties (Thorgaard 1983; Ihssen et al. 1990; Benfey 1999; Piferrer et al. 2009).

Triploidization of some commercial species including rainbow trout Oncorhynchus mykiss, Atlantic salmon Salmo salar, and grass carp Ctenopharyngodon idella has been practiced on a large scale for many years (Benfey 2001; Piferrer et al. 2009; Zajicek et al. 2011; Taylor et al. 2013). Induced triploidy is associated with measurable differences between sexes in the degree of gonad development, with both male and female remaining sterile and unable to produce viable offspring (Peruzzi et al. 2009). Functional sterility with no egg production has been obtained by triploidization in several teleost species, including coho salmon Oncorhynchus kisutch (Benfey \& Sutterlin 1984b), tench Tinca tinca (Flajšhans et al. 1997), Eurasian perch Perca fluviatilis (Rougeot et al. 2003), turbot Scophthalmus maximus (Cal et al. 2006), and European sea bass Dicentrarchus labrax (Felip et al. 2001a; Peruzzi et al. 2004). This phenomenon exists in a proportion of triploid females, 
as triploidization interferes with the normal pairing of homologous chromosomes during the initial phase of meiosis and inhibits further gamete development due to insufficient production of hormone in the theca and granulose layers of the ovarian follicles (SchafhauserSmith \& Benfey 2003). Triploid females produce small numbers of oogonia and few primary oocytes (Johnstone et al. 1993; Benfey 1999; Devlin \& Nagahama 2002). Eggs are undeveloped, unfertilizable, and few in number (Benfey \& Sutterlin 1984b; Piferrer et al. 1994; Gillet et al. 2001). In contrast, meiosis occurs in males with the onset of puberty, after spermatogonia have gone through many rounds of cell division by mitosis. The testes of triploid males can be developed to a size similar to those of diploids, with a considerable population of fully functional steroidogenic cells (Felip et al. 2001b; Piferrer et al. 2009).

Functional sterility in triploid males has been confirmed in several species including European sea bass (Felip et al. 2001a; Peruzzi et al. 2004), turbot (Cal et al. 2006), gilthead sea bream Sparus aurata (Haffray et al. 2005), and Arctic charr Salvelinus alpinus (Gillet et al. 2001). However, some important aquaculture species, including Atlantic salmon (Benfey \& Sutterlin 1984a), coho salmon (Piferrer et al. 1994), and tench (Linhart et al. 2006), are capable of producing small numbers of aneuploid spermatozoa, but these are unable to generate viable offspring. Induced triploidy primarily confers genetic sterility, producing competent hosts for germ cell transplantation by providing an environment favourable for germ cell colonization and development to produce functional eggs and sperm (Okutsu et al. 2007; Yoshizaki et al. 2010, 2012).

\section{Hybridization}

Hybridization is a reliable approach to improving aquaculture production, in which genetically distinct individuals (intraspecific hybridization) or separate species (interspecific hybridization) are crossbred. This technique shows potential in commercial fish production, because the hybrids retain characteristics of parent species. Production of hybrid individuals through interspecific crosses frequently results in offspring that are sterile or show reduced reproductive capacity and may be valuable as hosts for germline production. Sterility among fish hybrids can be categorized as zygotic, gametic, or gonadal (Chevassus 1983). In zygotic sterility, the gametes are normal in size and structure, and fertilization takes place, but embryos do not develop. Gametic sterility is that in which the gonads are normal in size but impaired with respect to gametogenesis. Gonadal sterility is characterized by a reduction in gonad size. Hybrid offspring of the Japanese medaka Oryzias latipes and Chinese Hainan medaka Oryzias curvinotus appear to be healthy and show a more rapid growth rate than normal, but are sterile (Hamaguchi \& Sakaizumi 1992). The gonads of these hybrids are sexually differentiated but oogenesis and spermatogenesis are severely impaired. With regard to these characteristics, a method was recently developed, in which hy- brids are used as transplant hosts for the production of viable offspring (Shimada \& Takeda 2008). However, many hybrids of both freshwater and marine species may not be sterile (Allen \& Wattendorf 1987; Smith 1988; Verdegem et al. 1997). Recently, zebrafish ovarian germ cells were successfully transplanted into the gonad of a hybrid male zebrafish larva, and cells subsequently colonized and differentiated into functional spermatozoa (Wong et al. 2011).

Germ cell transplantation using hybrid fish has been successful in the production of germline chimeras. Ovarian germ cells transplanted into two-week old sterile hybrid zebrafish larvae successfully colonized the gonad and differentiated into functional spermatozoa (Wong et al. 2011). The transplant system described in that study provides a reliable strategy to produce germline chimeras through a hybrid recipient. Use of infertile recipients optimizes the efficiency of germline chimera production and produces only donor-derived gametes. Further investigation is needed to evaluate use of sterile hybrids as hosts in germ cell transplantation.

\section{Knockdown of germline specific genes}

Primordial germ cells (PGCs) are the precursor cells of both female and male gametes. They are initially generated outside the gonad region and subsequently migrate to the genital ridges (Sawatari et al. 2007; Saito et al. 2008; Xu et al. 2010). In vertebrates, inheritance of specific asymmetrically localized cytoplasmic components, known as germplasm, are known to play an important role in specification and development of PGCs (Knaut et al. 2000; Tsunekawa et al. 2000). Many highly conserved genes are involved. Large numbers of genes are known to be important for germplasm function in invertebrates, whereas few involved genes have been identified in vertebrates (Saffman \& Lasko 1999; Koprunner et al. 2001).

Better understanding of the molecular mechanisms involved in PGCs development in fish requires isolation and identification of genes that are expressed in these cells during embryonic development. The first detected molecular marker for PGCs in fish was the vasa homologue transcript vas RNA (Yoon et al. 1997), while other factors, such as ziwi (Houwing et al. 2007), buckyball (Bontems et al. 2009), nanos 3 (Koprunner et al. 2001; Draper et al. 2007; Presslauer et al. 2012), staufen (Ramasamy et al. 2006), dead end (Weidinger et al. 2003; Liu et al. 2009), hmgcr (Thorpe et al. 2004), Igf (Schlueter et al. 2007), and Pik3 (Dumstrei et al. 2004) have been determined to stimulate PGCs formation and migration. Restriction of genes that are involved in specification and development of PGCs can be achieved by injection of morpholino oligonucleotide, providing the appropriate environment for colonization by transplanted donor PGCs (Ciruna et al. 2002; Saito et al. 2008). The above mentioned proteins are essential for normal migration and survival of PGCs, and embryos lacking the entire complex will develop into sterile fish. 
Gene knockdown is a technique by which the expression of one or more of an organism's genes is suppressed. This can be accomplished by treatment with a reagent, such as a short DNA or RNA oligonucleotide that has a complementary sequence to a target gene or an mRNA transcript (Summerton 2007). In most studied species, PGC development and migration are controlled by genes and signal pathways (Raz \& ReichmanFried 2006; Li et al. 2009; Xu et al. 2010). The genes involved in PGCs development and migration are also essential for maintaining viable germ cells, and silencing them has been demonstrated to result in sterility. Failure of PGCs to properly migrate during embryonic development can lead to sterility (Weidinger et al. 2002; Slanchev et al. 2005). Agents that temporarily suppress the expression of selected genes are commonly referred to as antisense or gene knockdown agents. To date, two major gene knockdown agents, small interfering RNA (siRNA) and morpholino, have been utilized in fish (Summerton 1999, 2007). Currently, application of morpholino predominates, due to its stability in biological systems and highly predictable targeting (Summerston 2007). In zebrafish, a nanos-related gene, nos1, has been identified as an important germplasm component expressed in PGCs (Koprunner et al. 2001). It has also been shown that the dead end (dnd) gene is localized on PGCs of zebrafish for encoding an RNA-binding protein. Knockdown of dnd blocks PGCs specification and results in failure of PGCs to actively migrate (Weidinger et al. 2003).

\section{Morpholino oligonucleotide antisense}

Morpholino antisense consists of chemically modified oligonucleotides (MOs) that are used as tools for reverse genetics by knocking down gene function (Summerton 1999; Draper et al. 2001). The MOs application reduces gene expression via steric blocking of pre-mRNA splicing or translation (Galderisi et al. 1999; Summerston 1999; Morcos 2007). The MOs have been employed for studying the role of genes and disrupting their expression during fish embryonic development (Ekker \& Larson 2001; Shepherd et al. 2001; Boonanuntanasarn et al. 2002). Although many researchers have used MOs to assess gene function in fish, few studies have applied this approach to specifically suppress genes involved in embryonic PGCs development. Effective gene knockdown using MOs has been demonstrated in transgenic rainbow trout and zebrafish, suggesting the value of investigating this tool in other teleosts, based on its rate of interference with target genes (Nacevecious \& Ekker 2000; Boonanuntanasarn et al. 2002). Boonanuntanasarn et al. (2002) demonstrated that injection of $10 \mathrm{ng}$ of MOs per rainbow trout embryo could effectively interfere with specific genes, while doses of $1-5 \mathrm{ng}$ were reported to be effective in zebrafish (Nacevecious \& Ekker 2000). Zebrafish PGCs were also ablated by nos1, which is responsible for the PGCs migration (Koprunner et al. 2001). The dnd silencing has been successfully employed to induce sterility without affecting somatic development (Slanchev et al. 2005; Škugor et al. 2014). The larvae of Atlantic cod subjected to dnd knockdown using MOs injected into two-cell embryos showed a decrease in vasa, nanos3, and tudor domain expression (Škugor et al. 2014). Injection of morpholino into one or two-celled zebrafish embryos produced similar results, along with high mortality rate and a variety of phenotypic abnormalities (Daya et al. 2014). Slightly reduced body length, smaller eyes, curved tail, and a short underdeveloped trunk, as well as reduced locomotor activity and impaired muscle integrity, including a reduction in the number of muscle fibres were the main reported effects (Daya et al. 2014). Hence, the dose required to affect PGCs development must be adjusted according to species to avoid undesired side effects. Development of anti-sense knockdown techniques will allow identification of more genes and the characterization of molecular mechanisms governing PGCs formation and migration patterns as well as provide tools for manipulating germline stem cells for research in reproductive biotechnology for aquaculture applications.

\section{Small interfering $R N A$ (siRNA)}

siRNA is an agent employed to disrupt expression of maternally inherited mRNA via interference with the expression of specific with complementary nucleotide sequences. siRNA functions by causing mRNA to be broken down after transcription, resulting in no translation (Summerston 2007). The use of siRNA to silence gene expression in fish has been studied using small double-stranded RNAs (dsRNA) and siRNA. Wargelius et al. (1999), for the first time, injected dsRNAs into zebrafish embryos at the one to two-cell stage and found a small proportion of the embryos to develop gene-specific defects. Several authors have demonstrated non-specific effects in fish embryos treated with siRNAs or dsRNAs, due either to toxicity (Oates et al. 2000; Zhao et al. 2001) or type-1 interferon stimulation (Li et al. 2000). The activity of the dnd gene in zebrafish embryos has been successfully inhibited by injection of siRNA (Dodd et al. 2004), but fish showed non-specific defects similar to those seen with dsRNA injection (Gruber et al. 2005). siRNA shows potential for gene knockdown in transgenic rainbow trout carrying the green fluorescent protein (GFP) gene during embryonic development by demonstrating that siRNAs can effectively inhibit the expression of GFP genes in embryos (Boonanuntanasarn et al. 2003). The researchers found that siRNA did not interfere with the expression of non-relevant genes, indicating gene knockdown effects of siRNAs are highly sequence-specific.

\section{Transgenic fish}

Transgenic sterilization is obtained mainly by targeted disruption or decrease of genes regulating reproductive hormones, and the induced sterility can be reversed by exogenous hormone administration. Reproductive function can hypothetically be modified by targeting the gene coding for a crucial reproductive hormone (gene 
knockout) or its specific gene message (gene knockdown) (Maclean et al. 2003). Gene knockout can be defined as the recognition and replacement of a genetic sequence with a copy via homologous recombination. In this technique, a construct is designed to act on target genes, rendering fish infertile by disrupting gametogenesis or embryogenesis. Disruption of the gonadotropin releasing hormone $(\mathrm{GnRH})$ pathway has been achieved in several fish species by the introduction of a transgene that encodes antisense RNA that blocks GnRH expression (Uzbekova et al. 2000; Hu et al. 2007). However, studies have revealed that a level of $\mathrm{GnRH}$ expression persists in the transgenic fish, resulting in a failure to induce complete sterility (Uzbekova et al. 2000).

Transgenic sterile fish may also be useful for germ cell visualization as host, recipient, or a surrogate system for germ cell transplantation (Okutsu et al. 2007; Yoshizaki et al. 2010). Germ cells have been visualized in transgenic rainbow trout and zebrafish (Yoshizaki et al. 2000; Hsiao \& Tsa 2003). In the transgene rainbow trout, GFP labelled PGCs could differentiate into spermatozoa when introduced into host masu salmon Oncorhynchus masou (Takeuchi et al. 2002). Sterilization methods using transgenic fish have been developed, including disruption of germ cell development in fish embryos without affecting other characteristics, resulting in an otherwise normal sterile fish. The method includes the production of a transgenic line of zebrafish carrying a construct, Tg (hsp70:sdf1a-nanos3, EGFP), that can control autocrine expression of stromal-derived factor-1alpha (Sdf1a) by PGCs, a chemokine that has been identified as the key to PGC migration (Raz \& Reichman-Fried 2006). Activation of hsp70 promoter required that the embryos be exposed to water temperatures of $32.5-34.5^{\circ} \mathrm{C}$, which resulted in migration of the PGCs to ectopic locations, such as tail and head. These embryos developed into infertile adult fish. When the transgenic embryos were incubated at $28.5^{\circ} \mathrm{C}$, and when reared in ideal growth conditions, PGCs migration was normal, and the adult fish showed normal gametogenesis (Wong \& Collodi 2013).

Lin et al. (2013) employed Cre-loxP technology, a system using recombination that facilitates replication of genomic DNA in bacteriophages developed for genome manipulation in mammals and in zebrafish. However, they did not achieve 100\% sterility. Qiu et al. (2014) also knocked out a GFP transgene in medaka Oryzias latipes by affecting its translation and synthesis using transcription activator-like effector nucleases. These engineered factors allow targeted gene disruption, generating genetic alterations in animal genomes.

The prokaryotic CRISPR/Cas9 genome editing system (Seruggia \& Montoliu 2014) is a novel editing tool that can facilitate genetic modification of most model organisms, including sterilization of fish. Hruscha et al. (2013) demonstrated that CRISPR/Cas9 mutagenesis in zebrafish can reach $86.0 \%$, and results are heritable. The design and generation of this system is less costly and time consuming than the more commonly used genome editing zinc-finger nucleases and transcrip- tion activator-like effector nucleases, and it also facilitated the targeted knock-in of a protein tag provided by a donor oligonucleotide, demonstrating its specificity.

One of the most important advantages of genome editing tools is that they avoid toxicity and non-specific phenotypes caused by off-target effects, as frequently seen in conventional knock-down approaches (Schmid \& Hass 2013). For sterility without unwanted effects, transgenesis is a convenient approach, although lack of strong stem cell lines with chimeric competence makes gene transfer for integration of a transgene into the host genome difficult in fish (Chen et al. 2007). Therefore, while transgenesis is feasible for sterilization in aquaculture, its application to germ cell transplantation in commercial fish species is problematic for reasons including the difficulty in producing transgenic fish and ensuring their physical and biological containment, as well as consumer attitudes to genetically modified fish. Further investigations are required to determine the potential of this approach in aquaculture.

\section{Assessment of fish sterility}

\section{Gonadosomatic index (GSI)}

Several parameters are commonly used to assess effectiveness of methods of fish sterilization. It has been shown that GSI considerably decreases following exposure to busulfan in conjunction with high water temperature (Mahji et al. 2009a). Assessment of GSI of $P$. pejerrey following busulfan plus temperature modifications has shown dose-dependent decreases of GSI in both sexes (Mahji et al. 2009b). Mahji et al. (2014) reported similar results in males following heat and busulfan treatment, but no significant changes were observed in treated females. In zebrafish, the combination of high water temperature plus a single dose of busulfan at 30 or $40 \mathrm{mg} / \mathrm{kg}$ body weight induced progressively decreasing GSI, culminating in over $80 \%$ of the spermatogenic tubules showing Sertoli cell appearance and total elimination of spermatogonia germ cells (Nobrega et al. 2010). However, when busulfan was injected into rainbow trout and tetra at optimal water temperature, GSI was not different from controls (Bilard 1982; de Siqueira-Silva et al. 2015). Adult tetra held at $35^{\circ} \mathrm{C}$ for 6 weeks showed a significant decrease of GSI, from 3.4 to 0.77 , and a reduction of more than $90 \%$ of germ cells in the seminiferous tubules (de Siqueira-Silva et al. 2015) (Fig. 2). Hamasaki et al. (2013) used GSI as a tool to determine fertility in triploid Takifugu niphobles. Although the testes and ovaries of triploid and diploid specimens showed similar structure, the GSI of triploids was significantly lower than that of diploids in both males and females during the experimental period, at $38 \%$ and $42 \%$ of diploid levels at 1 and 2 years, respectively. Linhart et al. (2006) showed high but nonsignificant difference in GSI of testes of diploid and triploid tench. Triploid males exhibited obvious secondary sex characteristics and showed high rates of fertilization. 


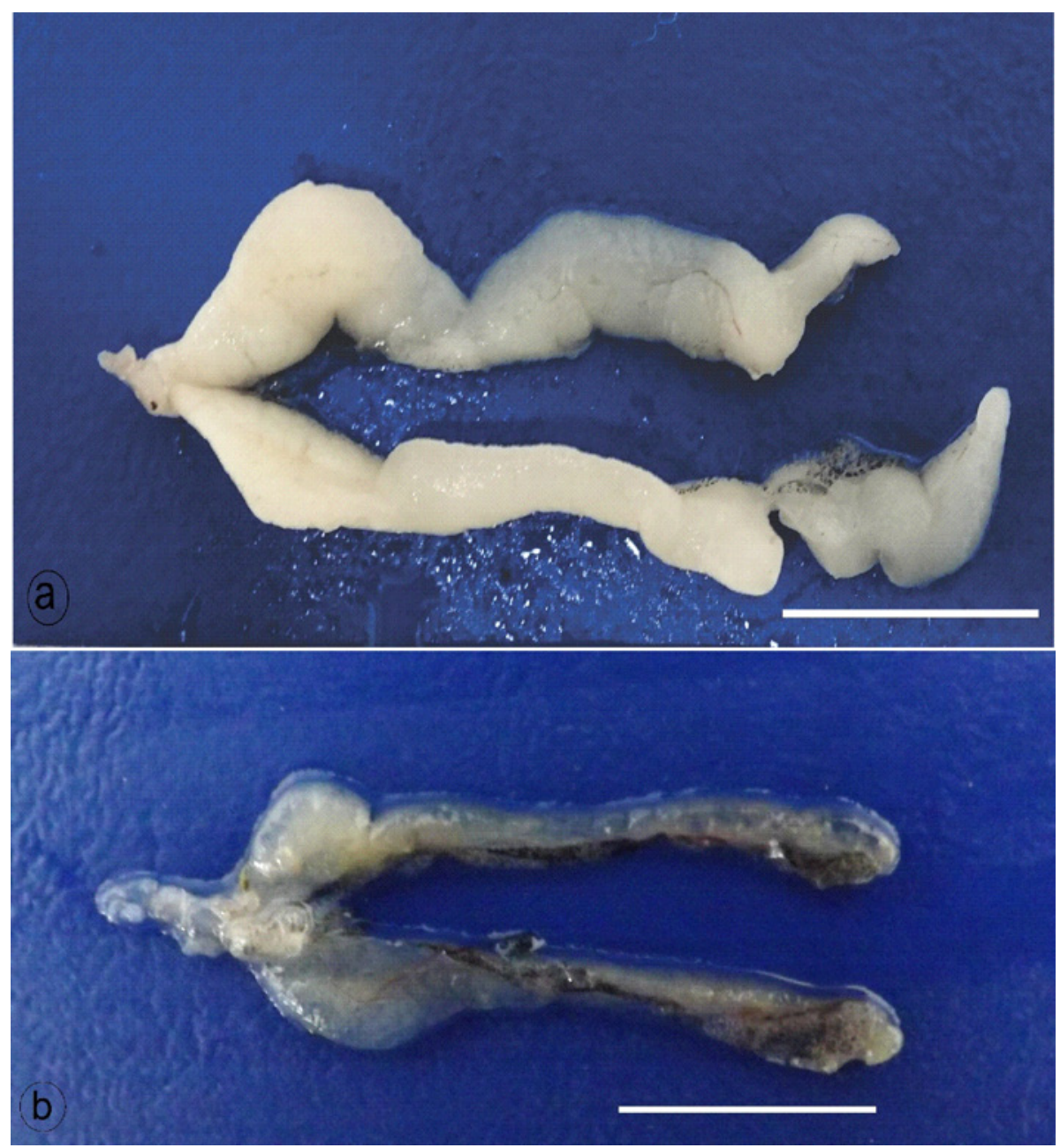

Fig. 2. Macroscopic image of testes of Astyanax altiparanae in control group held at $28^{\circ} \mathrm{C}$ (a) and busulfan treated fish at $35^{\circ} \mathrm{C}(\mathrm{b})$, 6 weeks after initiation of treatment. The testes of treated fish were visibly smaller than the control fish testes and were also darker, due to spermatogenesis suppression. Scale bars indicate $1 \mathrm{~cm}$. These photos were originally taken by Diógenes Henrique Siqueira-Silva (co-author of the present paper) during his experiment.

\section{Gonad histology}

Qualitative and quantitative histological examination of gonads is a promising tool to determine degree of germ cell loss and investigate features of germ cell and gonad degeneration (Mahji et al. 2009a). Stereological investigation of testes of tilapia showed Leydig cell morphology and volume to be unaffected by busulfan treatment (Lacerda et al. 2006, 2010). However, endogenous spermatogenesis was considerably depleted, and most seminiferous tubules of busulfan-treated animals contained Sertoli cells only. Somatic cells were not affected in medaka Oryzias latipes embryos exposed to busulfan (Shinomiya et al. 2001). The number of spermatogonia per unit area of $P$. pejerrey gonad demonstrated substantial loss of germ cells in both sexes with busulfan injection (Mahji et al. 2009b). Characteristics of histological degeneration of gonad in busulfan-treated male and female fish have been reported to consist of shrunken germinal epithelium with small cysts of spermatogonia, abnormal spermatogonia, minor atrophy of ovigerous lamella, fewer oocytes, and degenerated oogonia (Mahji et al. 2009b; Mahji et al. 2014). Thermo-chemical treatment of sub-adults and sexually mature $P$. pejerrey resulted in severe depletion of germ cells, but not com- plete sterility (Mahji et al. 2009b). These authors also observed ulcerations and mortality in busulfan-treated fish. Several weeks following busulfan treatment, germ cells were re-established in the gonads, resulting in generation of functional gametes.

Gonads of $O$. bonariensis and P. pejerrey exposed to elevated water temperature have been reported to show apoptotic somatic and germ cell degeneration with the dynamics and severity of damage proportional to the magnitude of the thermal stress (Ito et al. 2008a,b). Males were more sensitive to heat stress than were females (Ito et al. 2008a,b; Strüsman et al. 1998). Pathological alterations of gonads in juvenile Senegalese sole were detected with $40 \mathrm{mg} / \mathrm{kg}$ busulfan, with females more affected than males in terms of germ cell disruption (Pacchiarini et al. 2014).

\section{Molecular approaches}

Genes involved in gametogenesis can be utilized to monitor the degree of germ cell loss after induction of sterility. In this context, molecular approaches can be useful for assessing the degree of gonadal sterility. In most species, studies have revealed specific expression of vasa (an RNA binding protein) in germ cells. Thus, vasa 
can be considered a candidate for identifying germ cells (Wu et al. 2014). Vasa isoforms have been identified in species including zebrafish (Yoon et al. 1997), tilapia (Kobayashi et al. 2002), Senegalese sole (Pacchiarini et al. 2013), and Japanese flounder Paralichthys olivaceus (Wu et al. 2014). A similar pattern has been found for germ cell genes, such as boule and dazl in medaka $O$. latipes (Xu et al. 2009) and dazl in rainbow trout ( $\mathrm{Li}$ et al. 2011). Transcripts of Ssvasa1-2 and Ssvasa3-4 genes have been characterized in immature gonads of juvenile Senegalese sole (Pacchiarini et al. 2013). Vasa transcript in $O$. hatcheri examined by in situ hybridization and real-time PCR revealed the lowest level to be associated with the highest dose of busulfan. Histological findings were corroborated by real-time PCR analysis, and showed that vasa transcript levels were lower at higher busulfan doses (Mahji et al. 2009a; Mahji et al. 2014). In zebrafish, the expression of germ cell specific genes including piwil1 and sycp3l showed significant decrease in busulfan-treated animals (Nobrega et al. 2010).

Alterations in specific genes were also noted by quantitative PCR (qPCR) analyses of germ cells in both sexes of juvenile Senegalese sole after treatment with busulfan (Pacchiarini et al. 2014). The qPCR results showed no significant differences between expression of Ssvasa1-2 and Ssvasa3-4 transcripts in the testis of busulfan-treated juveniles compared with a control group. In females, a significant decrease in the expression of theSsvasa3-4 was found in treated individuals compared with controls (Pacchiarini et al. 2014). The qPCR analysis of two-celled Atlantic cod embryos, in which dnd knockdown was induced using MOs, revealed decreased vasa, nanos3, and tudor mRNA expression (Škugor et al. 2014). Microarray analyses indicated profound suppression of genes involved in development and regulation of the reproductive system (Škugor et al. 2014).

\section{Conclusion}

Sterilization in aquaculture has been considered a challenge due to strong selection pressure for the reversion to fertility. In aquaculture, if sterility is the sole aim, the practicable approaches are limited to triploidy and transgenics. Gene knockdown approaches are not feasible, as many methods are still in the preliminary stages of evaluation and not available for commercial application. While production of sterile fish is possible, there is no assurance of sterility using these complex methods in large-scale aquaculture operations. Strategies to reliably produce sterility can be useful for conservation of genetic stock of endangered and valuable species. Further studies are needed to determine the full potential of the range of available methods in aquaculture.

\section{Acknowledgements}

The study was financially supported by the Ministry of Education, Youth and Sports of the Czech Republic - projects
CENAKVA (No. CZ.1.05/2.1.00/01.0024) and CENAKVA II (No. LO1205 under the NPU I program), and by the Grant Agency of the University of South Bohemia in Ceske Budejovice (No. 125/2016/Z) and by the Czech Science Foundation (No. P502/13/26952S).

\section{References}

Allen S.K.J. \& Wattendorf R.J. 1987. Triploid grass carp: status and management implications. Fisheries 12: 20-24.

Arai K. 2001. Genetic improvement of aquaculture finfish species by chromosome manipulation techniques in Japan. Aquaculture 197: 205-228.

Bart A.N. \& Dunham R.A., 1990. Factors affecting survival of channel catfish after surgical removal of testes. Progressive Fish Culturist 52: 241-246.

Bartley D.M., Rana K. \& Immink A.J. 2001. The use of interspecific hybrids in aquaculture and fisheries. Rev. Fish Biol. Fish. 10: 325-337.

Beaumont A.R. \& Fairbrother J.E. 1991. Ploidy manipulation in molluscan shellfish: a review. J. Shellfish Res. 10: 1-18.

Benfey T.J. 1999. The physiology and behavior of triploid fishes. Rev. Fish. Sci. 7: 39-67.

Benfey T.J., 2001. Use of sterile triploid Atlantic salmon (Salmo salar L.) for aquaculture in New Brunswick, Canada. ICES J. Mar. Sci. 58: 525-529.

Benfey T.J., Bosa P.G., Richardson N.L. \& Donaldson E.M. 1988. Effectiveness of a commercial-scale pressure shocking device for producing triploid salmonids. Aquacult. Eng. 7: 147-154.

Benfey T.J. \& Sutterlin, A.M. 1984a. Growth and gonadal development in triploid landlocked Atlantic salmon (Salmo salar). Can. J. Fish. Aquat. Sci. 41: 1387-1392.

Benfey T.J. \& Sutterlin, A.M. 1984b. Triploidy induced by heat shock and hydrostatic pressure in landlocked Atlantic salmon (Salmo salar L.) Aquaculture 4: 359-367.

Billard R. 1982. Attempts to inhibit testicular growth in rainbow trout with anti-androgens (cyproterone, cyproterone acetate, oxymetholone) and busulfan given during the period of spermatogenesis. Gen. Comp. Endocrinol. 1: 33-38.

Bonham K. \& Donaldson L.R. 1972. Sex ratios and retardation of gonadal development in chronically gamma irradiated Chinook salmon smolts. Transact. Amer. Fish. Soc. 3: 428-423.

Bontems F., Stein A., Marlow F., Lyautey J., Gupta T., Mullins M.C. \& Dosch R. 2009. Bucky ball organizes germ plasm assembly in zebrafish. Curr. Biol. 19: 414-422.

Boonanuntanasarn S., Yoshizaki G. \& Takeuchi T., 2003. Specific gene silencing using small interfering RNAs in fish embryos. Biochem. Biophys. Res. Commun. 310: 1089-1095.

Boonanuntanasarn S., Yoshizaki G., Takeuchi Y., Morita T. \& Takeuchi T. 2002. Gene: knock-down in rainbow trout embryos using antisense morpholino phosphorodiamidate oligonucleotides. Mar. Biotechnol. 4: 256-266.

Brinster R.L. 2002. Germline stem cell transplantation and transgenesis. Science 296: 2174-2175.

Brinster R.L. \& Avarbock M.R. 1994. Germline transmission of donor haplotype following spermatogonial transplantation. Proc. Natl. Acad. Sci. USA 91: 11303-11307.

Bucci L.R. \& Meistrich M.L. 1987. Effects of busulfan on murine spermatogenesis: cytotoxicity, sterility, sperm abnormalities, and dominant lethal mutations. Mutat. Res. 176: 259-268.

Byamungua N., Darras VM. \& Kühn ER. 2001. Growth of heatshock induced triploids of blue tilapia, Oreochromis aureus, reared in tanks and in ponds in Eastern Congo 1: feeding regimes and compensatory growth response of triploid females. Aquaculture 1-2: 109-122.

Cal R.M., Vidal S., Gómez C., Álvarez-Blázquez B., Martínez P. \& Piferrer F. 2006. Growth and gonadal development in diploid and triploid turbot (Scophthalmus maximus). Aquaculture 251: 99-108. 
Chen S.L., Sha Z.X. Ye H.Q., Liu Y., Tian Y.S., Hong Y. \& Tang Q.S. 2007. Pluripotency and chimera competence of an embryonic stem cell line from the sea perch (Lateolabrax japonicus). Mar. Biotechnol. 1: 82-91.

Cherfas N.B., Gomelsky B., Ben-Dom N., Peretz Y. \& Hulata G. 1994. Assessment of triploid common carp (Cyprinus carpio L.) for culture. Aquaculture 1: 11-18.

Chevassus B. 1983. Hybridization in fish. Aquaculture 33: 245262 .

Chourrout D., Chevassus B., Krieg F., Happe A., Burger G. \& Renard P. 1986. Production of second generation triploid and tetraploid rainbow trout by mating tetraploid males and diploid females. Potential of tetraploid fish. Theor. Appl. Genet. 72: 193-206.

Ciruna B., Weidinger G., Knaut H., Thisse B., Thisse C., Raz E. \& Schier A.F. 2002. Production of maternal-zygotic mutant zebrafish by germ-line replacement. Proc. Natl. Acad. Sci. USA 99: 14919-14924.

Daya A., Vatine G.D., Becker-Cohen M., Tal-Goldberg T., Friedmann A., Gothilf Y., Du S.J. \& Mitrani-Rosenbaum S. 2014. Gne depletion during zebrafish development impairs skeletal muscle structure and function. Hum. Mol. Gen. 13: 3349 3361.

de Siqueira-Silva, D.H., dos Santos Silva, A.P., Ninhaus-Silveira, A., Verissimo-Silveira R. 2015. The effects of temperature and busulfan (Myleran) on yellowtail tetra Astyanax altiparanae (Pisces, Characiformes) spermatogenesis. Theriogenology 6: 1033-1042.

Devlin R.H. \& Nagahama Y. 2002. Sex determination and sex differentiation in fish: an overview of genetic, physiological, and environmental influences. Aquaculture 208: 191-364.

Dodd A., Chambers S.P. \& Love D.R. 2004. Short interfering RNA-mediated gene targeting in the zebrafish. FEBS Letters. 561: 89-93.

Draper B.W., McCallum C.M. \& Moens C.B. 2007. Nanos1 is required to maintain oocyte production in adult zebrafish. Dev. Biol. 305: 589-598.

Draper W.B., Morcos P.A. \& Kimmel C.B. 2001. Inhibition of zebrafish fgf8 pre-mRNA splicing with morpholino oligos: a quantifiable method for gene knockdown. Genesis 30: 154156.

Dumstrei K., Mennecke R. \& Raz E. 2004. Signaling pathways controlling primordial germ cell migration in zebrafish. J. Cell. Sci. 117: 4787-4795.

Ekker S.C. \& Larson J.D. 2001. Morphant technology in Mmodel developmental systems. Genesis 30: 89-93.

Felip A., Piferrer F., Carrillo M. \& Zanuy S. 2001a. Comparative growth performance between diploid and triploid sea bass (Dicentrarchus labrax L.) over the first four spawning seasons. J. Fish. Biol. 58: 76-88.

Felip A., Zanuy S., Carrillo M., Martínez G., Ramos J. \& Piferrer F. 1997. Optimal conditions for the induction of triploidy in the sea bass (Dicentrarchus labrax L.). Aquaculture 152: 287-298.

Felip A., Zanuy S., Carrillo M. \& Piferrer F. 2001b. Induction of triploidy and gynogenesis in teleost fish with emphasis on marine species. Genetica 111: 175-195.

França L.R., Ogawa T., Avarbock M.R., Brinster R.L. \& Russell L.D. 1998. Germ cell genotype controls cell cycle during spermatogenesis. Biol. Rep. 59: 1371-1377.

Francescon A., Barbaro A., Bertotto D., Libertini A., Cepollaro F., Richard J., Belvedere P. \& Colombo L. 2004. Assessment of homozygosity and fertility in meiotic gynogens of the European sea bass (Dicentrarchus labrax L.). Aquaculture 243: 93-102.

Fraser T.W.K., Fjelldal P.G., Hansen T. \& Maye I. 2012. Welfare considerations of triploid fish. Rev. Fish. Sci. 4: 192-211.

Galderisi U., Cascino A. \& Giordano A. 1999. Antisense oligonucleotides as therapeutic agents. J. Cell Physiol. 181: 251-257.

Gillet C., Vauchez C. \& Haffray P. 2001. Triploidy induced by pressure shock in Arctic charr (Salvelinus alpinus): growth, survival and maturation until the third year. Aquatic Living Resources 14: 327-334.
Gruber J., Manninga H., Tuschl T., Osborn M. \& Weber K. 2005. Specific RNAi mediated gene knockdown in zebrafish cell lines. RNA Biol. 2: 101-105.

Haffray P., Bruant J.S., Facqueur J.M. \& Fostier A. 2005. Gonad development, growth and quality traits in triploids of the protandrous hermaphrodite gilthead seabream Sparus aurata. Aquaculture 247: 107-117.

Hallerman E.M. \& Kapuscinski A.R. 1993. Genetic conservation of salmonid fishes, pp. 93-112. In: Cloud J.G. \& Thorgaard G.H. (eds), Potential Impacts of Transgenic and Genetically Manipulated Fish on Natural Populations. Plenum Press, New York.

Hallerman E.M. \& Kapuscinsky A.R. 1995. Incorporating risk assessment and risk management into public policies on genetically modified finfish and shellfish. Aquaculture 137: 9-17.

Hamaguchi S. \& Sakaizum M. 1992. Sexually differentiated mechanisms of sterility in interspecific hybrids between Oryzias latipes and O. curvinotus. J. Exp. Zool. 3: 323-329.

Hamasaki M., Takeuchi Y., Miyaki K. \& Yoshizaki G. 2013. Gonadal development and fertility of triploid grass puffer Takifugu niphobles induced by cold shock treatment. Mar. Biotechnol. 15: 133-144.

Holmefjord I. \& Refstie T. 1997. Induction of triploidy in Atlantic halibut by temperature shocks. Aquacult. Int. 5: 169-173.

Houwing S., Kamminga L.M., Berezikov E., Cronembold D., Girard A., Van den Elst H., Filippov D.V., Blaser H., Raz E., Moens C.B, Plasterk R.H, Hannon G.J., Draper B.W. \& Ketting R.F. 2007. A role for Piwi and piRNAs in germ cell maintenance and transposon silencing in zebrafish. Cell 129: 6982.

Hruscha A., Krawitz P., Rechenberg A., Heinrich V., Hecht J., Haass C. \& Schmid B. 2013. Efficient CRISPR/Cas9 genome editing with low off-target effects in zebrafish. Development 24: 4982-4987.

Hsiao C.D. \& Tsa H.J. 2003. Transgenic zebrafish with fluorescent germ cell: a useful tool to visualize germ cell proliferation and juvenile hermaphroditism in vivo. Dev. Biol. 262: 313-323.

Hsu C.C., Hou M.F., Hong J.R., Wu J.L. \& Her G.M. 2010. Inducible male infertility by targeted cell ablation in zebrafish testis. Mar. Biotechnol. 12: 466-478.

Hu S.Y., Lin P.Y., Liao C.H., Gong H.Y., Lin G.H., Kawakami K. \& Wu J.L. 2009. Nitroreductase mediated gonadal dysgenesis for infertility control of genetically modified zebrafish. Mar. Biotechnol. 12: 569-578.

Hu W., Li S., Tang B., Wang Y., Lin H., Liu X., Zou J. \& Zhu Z. 2007. Antisense for gonadotropin-releasing hormone reduces gonadotropin synthesis and gonadal development in transgenic common carp (Cyprinus carpio). Aquaculture 271: 498-506.

Ihssen P.E., McKay L.R, McMillan I. \& Phillips R.B. 1990. Ploidy manipulation and gynogenesis in fishes: cytogenetic and fisheries applications. Transact. Amer. Fish. Soc. 119: 698-717.

Ito L.S., Cornejo A.M., Yamashita M. \& Strüssmann C.A. 2008a. Thermal threshold and histological process of heat-induced sterility in adult pejerrey (Odontesthes bonariensis): a comparative analysis of laboratory and wild specimens. Physiol. Biochem. Zool. 81: 775-784.

Ito L.S., Takahashi C., Yamashita M. \& Strüssmann C.A. 2008b. Warm water induces apoptosis, gonadal degeneration, and germ cell loss in subadult pejerrey Odontesthes bonariensis (Pisces, Atheriniformes). Physiol. Biochem. Zool. 81: 762774.

Johnstone R. 1993. Maturity control in Atlantic salmon, pp. 99105. In: Muir J.F. \& Roberts R.J. (eds), Recent Advances in Aquaculture. Blackwell Scientific Publications, London.

Knaut H., Pelegri F., Bohmann K., Schwarz H. \& NussleinVolhard C. 2000. Zebrafish vasa RNA but not its protein is a component of the germ plasm and segregation asymmetrically before germline specification. J. Cell. Biol. 149: 875-888.

Kobayashi S. \& Mogami M. 1958. Effects of X-irradiation upon rainbow trout (Salmo irideus). III. Ovary growth in the stages 
of fry and fingerlings. Bull. Fac. Fish. Hokkaido Univ. 9: 89 94.

Kobayashi T., Kajiura-Kobayashi H. \& Nagahama Y., 2002. Two isoforms of vasa homologs in a teleost fish: their differential expression during germ cell differentiation. Mech. Dev. 111: 167-171.

Koprunner M., Thisse C., Thisse B. \& Raz E. 2001. A zebrafish nanos-related gene is essential for the development of primordial germ cells. Gen. Dev. 15: 2877-2885.

Kucharczyk D., Targońska K., Szczerbowski A., Łuczyński M., Rożek W., Kujawa R. \& Mamcarz A. 2008. Genetic inactivation of dace, Leuciscus leuciscus (L.), gametes using UV irradiation. Arch. Polish Fish. 4: 437-446.

Lacerda S.M.S.N., Batlouni S.R., Costa G.M., Segatelli T.M., Quirino B.R., Queiroz B.M., Kalapothakis E. \& França L.R. 2010. A new and fast technique to generate offspring after germ cells transplantation in adult fish: the Nile tilapia (Oreochromis niloticus) model. PLoS One 5: e10740.

Lacerda S.M.S.N., Batlouni S.R., Luiz H., Assis F., Resende M., Campos-Silva S.M., Campos-Silva R., Segatelli T.M. \& França L.R. 2008. Germ cell transplantation in tilapia (Oreochromis niloticus). Cybium 2: 115-118.

Lacerda S.M.S.N., Batlouni S.R., Silva S.B.G., Homem C.S.P. \& França L.R. 2006. Germ cells transplantation in fish: the Nile-tilapia model. Animal Rep. 2: 146-159.

Li M., Shen Q., Wong F.M., Xu H., Hong N., Zeng L., Liu L., Wei Q. \& Hong Y. 2011. Germ cell sex prior to meiosis in the rainbow trout. Protein Cell 1: 48-54.

Li M.Y., Hong N., Xu H., Yi M., Li C., Gui J.F. \& Hong Y. 2009. Medaka vasa are required for migration but not survival of primordial germ cells. Mech. Dev. 126: 366-381.

Lin H.J., Lee S.H., Wu J.L., Duann Y.F. \& Chen J.Y., 2013. Development of Cre-loxP technology in zebrafish to study the regulation of fish reproduction. Fish Physiol. Biochem. 39: 1525-1539.

Linhart O., Rodina M., Flajšhans M., Mavrodiev N., Nebesarova J., Gela D. \& Kocour M. 2006. Studies on sperm of diploid and triploid tench (Tinca tinca L.). Aquacult. Int. 14: 9-25.

Liu L., Hong N., Xu H., Li M., Yan Y., Purwanti Y., Yi M., Li Z., Wang L. \& Hong Y. 2009. Medaka dead end encodes a cytoplasmic protein and identifies embryonic and adult germ cells. Gene Expr. Patterns 9: 541-548.

Maclean N., Hwang G., Molina A., Ashton T., Muller M., Rahman M.A. \& Iyengar A. 2003. Reversibly-sterile fish via transgenesis. ISB News Report 12: 3-5.

Majhi S.K., Hattori R.S., Rahman S.M. \& Strussmann C.A. 2014. Surrogate production of eggs and sperm by intrapapillary transplantation of germ cells in cytoablated adult fish. PLoS One 4: e95294.

Majhi S.K., Hattori R.S., Rahman S.M., Suzuki T. \& Strussmann C.A. 2009a. Experimentally induced depletion of germ cells in sub-adult Patagonian pejerrey (Odontesthes hatcheri) Theriogenology 71: 1162-1172.

Majhi S.K., Hattori R.S., Yokota M., Watanabe S. \& Strussmann C.A. 2009b. Germ cell transplantation using sexually competent fish: an approach for rapid propagation of endangered and valuable germlines. PLoS One 7: e6132.

Morcos P.A. 2007. Achieving targeted and quantifiable alteration of mRNA splicing with morpholino oligos. Biochem. Biophys. Res. Commun. 358: 521-527.

Nam Y.K. \& Kim D.S. 2004. Ploidy status of progeny from the crosses between tetraploid males and diploid females in mud loach (Misgurnus mizolepis). Aquaculture 236: 575-582.

Nobrega R.H., Greebe C.D., van de Kant H., Bogerd J., de Franca L.R. \& Schulz R.W. 2010. Spermatogonial stem cell niche and spermatogonial stem cell transplantation in zebrafish. PLoS One 9: e12808.

Oates A.C., Bruce A.E.E. \& Ho R.K. 2000. Too much interference: injection of double stranded RNA has nonspecific effects in the zebrafish embryo. Dev. Biol. 224: 20-28.

Okutsu T., Shikina S., Kanno M., Takeuchi Y. \& Yoshizaki G. 2007. Production of trout offspring from triploid salmon parents. Science 317: 1517.
Pacchiarini T., Olague E., Sarasquete C. \& Cabrita E. 2014. Busulfan administration produces sublethal effects on somatic tissues and inhibits gametogenesis in Senegalese sole juveniles. Hist. Histopathol. 29: 619-628.

Pacchiarini T., Cross I., Leite R.B., Gavaia P., Ortiz-Delgado J.B, Pousao-Ferreira P., Rebordinos L., Sarasquete C. \& Cabrita E. 2013. Solea senegalensis vasa transcripts: molecular characterization, tissue distribution and developmental expression profiles. Reprod. Fertil. Dev. 25: 646-660.

Peruzzi, S. Chatain, B., Saillant E., Haffray P., Menu B. \& Falguiere J.C. 2004. Production of meiotic gynogenetic and triploid sea bass, Dicentrarchus labrax L.: performances, maturation and carcass quality. Aquaculture 230: 41-64.

Peruzzi S. \& Chatain B. 2000. Pressure and cold shock induction of meiotic gynogenesis and triploidy in the European sea bass, Dicentrarchus labrax L.: relative efficiency of methods and parental variability. Aquaculture 189: 23-37.

Peruzzi S., Rudolfsen G., Primicerio R., Frantzen M. \& Kauric G. 2009. Milt characteristics of diploid and triploid Atlantic cod (Gadus morhua L.). Aquacult. Res. 40: 1160-1169.

Piferrer F., Beaumont A., Falguiere J.C., Flajšhans M., Haffray P. \& Colombo L. 2009. Polyploid fish and shellfish: production, biology and applications to aquaculture for performance improvement and genetic containment. Aquaculture 293: 125156.

Piferrer F., Benfey T.J. \& Donaldson E.M. 1994. Gonadal morphology of normal and sex reversed triploid and gynogenetic diploid Coho salmon (Oncorhynchus kisutch). J. Fish. Biol. 45: 541-553.

Piferrer F., Cal R.M., Alvarez-Blazquez B., Sanchez L. \& Martinez P. 2000. Induction of triploidy in the turbot (Scophthalmus maximus). I. Ploidy determination and the effects of cold shocks. Aquaculture 188: 79-90.

Piferrer F., Cal R. M., Gomez C., Bouza C. \& Martinez P., 2003. Induction of triploidy in the turbot (Scophthalmus maximus) II. Effects of cold shock timing and induction of triploidy in a large volume of eggs. Aquaculture 220: 821-831.

Presslauer C., Nagasawa K., Fernandes J.M. \& Babiak I. 2012. Expression of vasa and nanos3 during primordial germ cell formation and migration in Atlantic cod (Gadus morhua L.). Theriogenology 78: 1262-1277.

Qiu C., Cheng B., Zhang Y., Huang R., Liao L., Li Y., Luo D., Hu W. \& Wang Y. 2014. Efficient knockout of transplanted green fluorescent protein gene in medaka using TALENs. Mar. Biotechnol. 6: 674-683.

Rahman M.A., Uehara T. \& Lawrence J.M. 2005. Growth and heterosis of hybrids of two closely related species of Pacific sea urchins (Genus Echinometra) in Okinawa. Aquaculture 245: $121-133$.

Ramasamy S., Wang H., Quach H.N. \& Sampath K. 2006. Zebrafish Staufen1 and Staufen2 are required for the survival and migration of primordial germ cells. Dev. Biol. 292: 393406.

Raz E. \& Reichman-Fried M. 2006. Attraction rules: germ cell migration in zebrafish. Curr. Opin. Gen. Dev. 4: 355-359.

Rougeot C., Minet L., Prignon C., Vanderplasschen A., Detry B., Pastoret P.P. \& Melard C. 2003. Induce triploidy by heat shock in Eurasian perch, Perca fluviatilis. Aquatic Living Resources 2: 90-94.

Saffman E.E. \& Lasko P. 1999. Germline development in vertebrates and invertebrates. Cell. Mol. Life Sci. 55: 1141-1163.

Solar I.I., Donaldson E.M. \& Hunter G.A. 1994. Induction of triploidy in rainbow trout (Salmo gairdneri Richardson) by heat shock, and investigation of early growth. Aquaculture 42: $57-67$.

Saito T., Goto-Kazeto R., Arai K. \& Yamaha E. 2008. Xenogenesis in teleost fish through generation of germ-line chimeras by single primordial germ cell transplantation. Biol. Rep. 78: 159-166.

Sawatari E., Shikina S., Takeuchi T. \& Yoshizaki G. 2007. A novel transforming growth factor- $\beta$ superfamily member expressed in gonadal somatic cells enhances primordial germ cell and 
spermatogonial proliferation in rainbow trout (Oncorhynchus mykiss). Dev. Biol. 301: 266-275.

Schafhauser-Smith D. \& Benfey T.J. 2003. In vitro steroid production by triploid ovarian follicles. Gen. Comp. Endocrinol. 133: 279-286.

Scheerer P.D. \& Thorgaard G.H. 1983. Increased survival in salmonid hybrids by induced triploidy. Can. J. Fish. Aquatic Sci. 11: 2040-2044.

Schlueter P.J., Sang X., Duan C. \& Wood A.W. 2007. Insulin-like growth factor receptor $1 \mathrm{~b}$ is required for zebrafish primordial germ cell migration and survival. Dev. Biol. 305: 377-387.

Schmid B. \& Haass C. 2013. Genomic editing opens new avenues for zebrafish as a model for neurodegeneration. Neurochemistry 127: 461-470.

Seruggia D. \& Montoliu L. 2014. The new CRISPR-Cas system: RNA-guided genome engineering to efficiently produce any desired genetic alteration in animals. Transgenic Res. 23: $707-716$.

Shepherd L.T., Beattie C.E. \& Raible D.W. 2001. Functional analysis of zebra fish GNDF. Dev. Biol. 231: 420-435.

Shimada A. \& Takeda H. 2008. Production of a maternal-zygotic medaka mutant using hybrid sterility. Dev. Growth Differ. 50: $421-426$.

Shinomiya A.I., Hamaguchi S. \& Shibata N. 2001. Sexual differentiation of germ cell deficient gonads in the medaka, Oryzias latipes. J. Exp. Zool. 290: 402-410.

Škugor A., Tveiten H., Krasnov A. \& Andersen O. 2014. Knockdown of the germ cell factor Dead end induces multiple transcriptional changes in Atlantic cod (Gadus morhua) hatchlings. Anim. Reprod. Sci. 144: 129-137.

Slanchev K., Stebler J., de la Cueva-Mendez G. \& Raz E. 2005. Development without germ cells: the role of the germ line in zebrafish sex differentiation. Proc. Natl. Acad. Sci. USA 102: 4074-4079.

Smith T.I.J. 1988. Aquaculture of striped bass and its hybrids in North America. Aquacult. Mag. 14: 40-49.

Strüssmann C.A., Saito T. \& Takashima F. 1998. Heat-induced germ cell deficiency in the teleosts Odontesthes bonariensis and Patagonina hatcheri. Comp. Biochem. Physiol. A Mol. Integr. Physiol. 119: 637-644.

Sui G., Soohoo C., Affar E.B., Gray F., Shi Y., Forrester W. \& Shi Y. 2002. A DNA vector-based RNAi technology to suppress gene expression in mammalian cells. Proc. Natl. Acad. Sci. USA 99: 5515-5520.

Summerton J. 1999. Morpholino antisense oligomers: the case for an RNAse-H independent structural type. Biochim. Biophys. Acta 1: 141-158.

Summerton J.E. 2007. Morpholino, siRNA, and S-DNA compared: impact of structure and mechanism of action on offtarget effects and sequence specificity. Curr. Top. Med. Chem. 7: $651-660$

Takeuchi Y., Yoshizaki G., Kobayashi T. \& Takeuchi T. 2002. Mass isolation of primordial germ cells from transgenic rainbow trout carrying the green fluorescent protein gene driven by the vasa gene promoter. Biol. Reprod. 67: 1087-1092.

Tashiro F. 1972. Effects of irradiation ${ }^{60} \mathrm{Co} \gamma$ ray on the maturation of rainbow trout. Bull. Jap. Soc. Sci. Fish. Niss. 38: $793-797$.

Taylor J.F., Sambraus F., Mota-Velasco J., Guy D.R., Hamilton A., Hunter D., Corrigan D. \& Migaud H. 2013. Ploidy and family effects on Atlantic salmon (Salmo salar) growth, deformity and harvest quality during a full commercial production cycle. Aquaculture 410-411: 41-50.

Thorgaard G.H. 1983. Chromosome set manipulation and sex control in fish, pp. 405-434. In: Hoar W.H., Randall D.J. \& Donaldson E.M. (eds), Fish Physiology. Academic Press, Belgium.

Thorpe J.L., Doitsidou M., Ho S.Y., Raz E. \& Farber S.A. 2004. Germ cell migration in zebrafish is dependent on HMGCoA reductase activity and prenylation. Dev. Cell. 6: 295-302.

Tsunekawa N., Naito M., Sakai Y., Nishida T. \& Noce T. 2000. Isolation of chicken vasa homolog gene and tracing the origin of primordial germ cells. Development 127: 2741-2750.
Um-E-Kalsoom S.M., Shahzadi T. \& Barlas A. 2009. Growth performance and feed conversion ratio (FCR) in hybrid fish (Catla catla $\times$ Labeo rohita) fed on wheat bran, rice broken and blood meal. Pak. Vet. J. 29: 55-58.

Underwood J.L., Hestand R.S., Thompson B.Z. 1986. Gonad regeneration in grass carp following bilateral gonadectomy. Progressive Fish Culturist 48: 54-56.

Uzbekova S., Chyb J., Ferrière F., Bailhache T., Prunet P., Alestrom P. \& Breton B. 2000. Transgenic rainbow trout expressed sGnRH-antisense RNA under the control of sGnRH promoter of Atlantic salmon. J. Mol. Endocrinol. 3: 337-50.

Verdegem M.C.J., Hilbrands A.D. \& Boon J.H. 1997. Influence of salinity and dietary composition on blood parameter values of hybrid red tilapia, Oreochromis niloticus $\times$ Oreochromis mossambicus. Aquacult. Res. 28: 453-459.

Wargelius A., Ellingsen S. \& Fjose A. 1999. Double-stranded RNA induces specific developmental defects in zebrafish embryos. Biochem. Biophys. Res. Commun. 263: 156-161.

Weidinger G., Stebler J., Slanchev K., Dumstrei K., Wise C., Lovell-Badge R., Thisse C., Thisse B. \& Raz E. 2003. Dead end, a novel vertebrate germ plasm component, is required for zebrafish primordial germ cell migration and survival. Curr. Biol. 13: 1429-1434.

Weidinger G., Wolke U., Köprunner M., Thisse C., Thisse B. \& Raz E. 2002. Regulation of zebrafish primordial germ cell migration by attraction towards an intermediate target. Development 129: $25-36$.

Withler R.E., Beacham T.D., Solar I.I. \& Donaldson E.M. 1995. Freshwater growth, smolting, and marine survival and growth of diploid and triploid coho salmon. (Oncorhynchus kisutch). Aquaculture 1-2: 91-107.

Wohlfarth G.W. 1994. The unexploited potential of tilapia hybrids in aquaculture. Aquat. Fish. Manag. 25: 781-788.

Wong T.T. \& Collodi P. 2013. Inducible sterilization of zebrafish by disruption of primordial germ cell migration. PLoS One 6: e68455.

Wong T.T., Saito T., Crodian J. \& Collodi P. 2011. Zebrafish germline chimeras produced by transplantation of ovarian germ cells into sterile host larvae. Biol. Reprod. 84: 11901197.

Wu X., Wang Z., Jiang J., Gao J., Wang J., Zhou X. \& Zhang Q. 2014. Cloning, expression promoter analysis of vasa gene in Japanese flounder (Paralichthys olivaceus). Comp. Biochem. Physiol. B Biochem. Mol. Biol. 167: 2014. 41-50.

Xu H., Li M., Gui J. \& Hong Y. 2010. Fish germ cells. Sci. China Life. Sci. 53: 435-446.

Xu H., Li Z., Li M., Wang L. \& Hong Y. 2009. Boule is present in fish and bisexually expressed in adult and embryonic germ cells of medaka. PLoS One 6: e6097.

Xu J., You F., Wu X., Zhang P., Lin Y., Jiang H. \& Zheng C. 2008. Induction of triploidy in large yellow croacker Pseudosciaena crocea (Richardson, 1846): effects of pressure shocks and growth performance in the first rearing year. Aquacult. Res. 39: 1369-1376.

Yamaha E. Murakami M., Hada K., Otani S., Fujimoto T., Tanaka M., Sakao S., Kimura S., Sato S. \& Arai K. 2003. Recovery of fertility in male hybrids of a cross between goldfish and common carp by transplantation of PGC (primordial germ cell)-containing graft. Genetica 119: 121-131.

Yamaha E., Saito T., Goto-Kazeto R. \& Arai K. 2007. Developmental biotechnology for aquaculture, with special reference to surrogate production in teleost fishes. J. Sea Res. 58: 8-22.

Yoon C., Kawakami K. \& Hopkins N. 1997. Zebrafish vasa homologue RNA is localized to the cleavage planes of 2- and 4-cell-stage embryos and is expressed in the primordial germ cells. Development 124: 3157-3166.

Yoshizaki G., Fujinuma K., Iwasaki Y., Okutsu T., Shikina S., Yazawa R. \& Takeuchi Y. 2010. Spermatogonial transplantation in fish: a novel method for the preservation of genetic resources. Comp. Biochem. Physiol. Part D Genomics Proteomics 6: 55-61.

Yoshizaki G., Okutsu T., Morita T., Terasawa M., Yazawa R. \& Takeuchi Y. 2012. Biological characteristics of fish germ 
cells and their application to developmental biotechnology. Reprod. Domest. Anim. 47: 187-192.

Zajicek P., Goodwin A.E. \& Weier T. 2011. Triploid grass carp: triploid induction, sterility, reversion, and certification. North Amer. J. Fish. Manag. 4: 614-618.
Zhao Z., Cao Y., Li M. \& Meng A. 2001. Double-stranded RNA injection produces nonspecific defects in zebrafish. Dev. Biol. 229: $215-223$.

Received January 29, 2016 Accepted August 13, 2016 